\title{
PREDICTION OF WATER QUALITY IN THE DANUBE RIVER UNDER EXTREME HYDROLOGICAL AND TEMPERATURE CONDITIONS
}

\author{
PAVLA PEKÁROVÁ ${ }^{1)}$, MILAN ONDERKA ${ }^{1)}$, JÁN PEKÁR ${ }^{2)}$, \\ PETER RONČÁK ${ }^{3)}$, PAVOL MIKLÁNEK ${ }^{1)}$ \\ ${ }^{1)}$ Institute of Hydrology, Slovak Academy of Sciences, Račianska 75, 83102 Bratislava 3, Slovakia; mailto: pekarova@uh.savba.sk \\ ${ }^{2)}$ Department of Applied Mathematics and Statistics, Faculty of Mathematics, Physics and Informatics Comenius University Brati- \\ slava, Mlynská dolina, 84248 Bratislava, Slovakia. \\ ${ }^{3)}$ Slovak Hydrometeorological Institute, Jeséniova 17, 83315 Bratislava, Slovakia.
}

One of the requirements imposed by the Water Framework Directive (WFD, 2000/60/EC) is to analyze and predict how quality of surface waters will evolve in the future. In assessing the development of a stream's pollution one must consider all sources of pollution and understand how water quality evolves over time. Flow and water temperature regime of a stream or river are the main factors controlling the extent to which deterioration of a stream's water quality can propagate under constant input from pollution sources. In addition, there is ever increasing public concern about the state of the aquatic environment. Decision makers and scientists involved in water management call for studies proposing simulation models of water quality under extreme natural hydrologic and climatic scenarios. Also, human impact on water resources remain an issue for discussion, especially when it comes to sustainability of water resources with respect to water quality and ecosystem health. In the present study we investigate the long-term trends in water quality variables of the Danube River at Bratislava, Slovakia (Chl-a, Ca, EC, $\mathrm{SO}_{4}{ }^{2-}, \mathrm{Cl}^{-}, \mathrm{O}_{2}, \mathrm{BOD}_{5}, \mathrm{~N}$-tot, $\mathrm{PO}_{4}-\mathrm{P}$, $\mathrm{NO}_{3}-\mathrm{N}, \mathrm{NO}_{2}-\mathrm{N}$, etc.), for the period 1991-2005. Several SARIMA models were tested for the long-term prediction of selected pollutant concentrations under various flow and water temperature conditions. In order to create scenarios of selected water quality variables with prediction for 12 months ahead, three types of possible hydrologic and water temperature conditions were defined: i) average conditions - median flows and water temperature; ii) low flows and high water temperature; and iii) high flows and low water temperature. These conditions were derived for each month using daily observations of water temperature and daily discharge readings taken in the Danube at Bratislava over the period 1931-2005 in the form of percentiles $\left(1^{\text {th }}\right.$-percentile, median, $99^{\text {th }}$-percentile). Once having derived these extreme-case scenarios, we used selected Box-Jenkins models (with two regressors - discharge and water temperature) to simulate the extreme monthly water quality variables. The impact of natural and man-made changes in a stream's hydrology on water quality can be readily well simulated by means of autoregressive models.

KEY WORDS: Danube River, Water Quality, SARIMA Models, Simulation.

Pavla Pekárová, Milan Onderka, Ján Pekár, Peter Rončák, Pavol Miklánek: PREDPOVEĎ VYBRANÝCH UKAZOVATELOOV KVALITY VODY VDUNAJI ZA EXTRÉMNYCH HYDROLOGICKÝCH A TEPLOTNÝCH PODMIENOK. J. Hydrol. Hydromech., 57, 2009, 1; 38 lit., 8 obr., 2 tab.

Jednou z požiadaviek Rámcovej smernice o vode (WFD, 2000/60/EC) je analýza trendov a dlhodobá predpoved' vývoja znečistenia povrchových tokov. Pri odhade vývoja znečistenia toku je potrebné brat' do úvahy nielen možné zdroje znečistenia, ale je potrebné uvažovat' aj s vývojom množstva vody v tokoch a so zvyšovaním teploty tokov $\mathrm{v}$ dôsledku očakávanej klimatickej zmeny a zmeny vo využívaní vodných zdrojov. V príspevku je analyzovaný vývoj mesačných koncentrácií vybraných ukazovatelov kvality vody $\mathrm{v}$ toku Dunaja v stanici Bratislava (napr. Chl-a, $\mathrm{Ca}, \mathrm{EC}, \mathrm{SO}_{4}{ }^{2-}, \mathrm{Cl}^{-}, \mathrm{O}_{2}, \mathrm{BSK}_{5}, \mathrm{~N}$-celk, $\mathrm{PO}_{4}-\mathrm{P}, \mathrm{NO}_{3}-\mathrm{N}, \mathrm{NO}_{2}-\mathrm{N}$ a pod.) za obdobie r. 1991-2005. Za účelom dlhodobej predpovede koncentrácií každého ukazovatela kvality vody sme na základe štatistických testov vybrali najlepší autoregresný Box-Jenkinsov model s dvoma regresormi: 1. prietokmi a 2. teplotami vody. Scenáre pre mesačné prietoky a mesačné teploty vody boli vytvorené pre tri stavy: i) priemerné podmienky - medián prietokov a teploty vody; ii) nízke prietoky a vysoké teploty vody; a iii) vysoké prietoky a nízke teploty vody. Tieto scenárové podmienky boli vypočítané z denných údajov z obdobia 1931-2005 ako percentily (1. percentil, medián, 99. percentil). Použijúc tieto 
scenáre sme vybranými Box-Jenkinsovými modelmi s dvoma regresormi simulovali extrémne mesačné hodnoty vybraných ukazovatel'om kvality vody v Dunaji pre extrémne hydrologické a teplotné podmienky.

KLÚČOVÉ SLOVÁ: Dunaj, kvalita vody, modely SARIMA, simulácia.

\section{Introduction}

Water quality of surface and ground waters continue to be an issue of public concern throughout the developed world. Over the last decades, there has been an increasing demand for monitoring water quality in rivers. This was invoked by the need to monitor changes in agricultural practice and decrease in sewage disposal into inland waters. Land use changes and construction of water reservoirs and water withdrawal for irrigation and industry may impose a serious threat to water quality downstream. Therefore it is important for water managers to be able to foresee possible consequences of such changes, whether natural or human-induces on water quality in streams. Gathering reliable historical water quality records makes it possible to examine the long-term trends in water quality in many surface waters (Antonopoulos et al., 2001; Ragavan and Fernandez, 2006). Spatial and temporal variability of surface water quality have been analyzed and used in various models by several authors. Decision makers and scientists involved in water management call for studies proposing simulations of water quality under extreme hydrologic and climatic scenarios.

Unprecedented development of water and soil resources, their exploitation and pollution, have taken place in most of the Danubian countries during the last five decades of the $20^{\text {th }}$ century (Literáthy, 1975; Reichel and Nachtnebel, 1994; Velikov et al., 1996; Wolf, 1996; Krizan and Miloradov, 1997; Weilguni and Humpesch, 1999; Somlyódy et al., 1999; Botterweg and Rodda, 1999; Langhammer, 2005; Bloesch, 2006; Sebin et al., 2007; Chalupova and Jansky, 2007). The issue of water pollution in the individual Danube-basin countries became one of the main topics for discussion also. An analysis of temporal variability of water quality in this area should be considered with respect to the EU WFD. Of special concern in the Upper Danube region is the ecological status of the Rye Inland area in the Slovak-Hungarian Danube River stretch. It is of utmost importance to ensure protection of this ecologically vulnerable and unique inland delta with flood plains and forested areas including RAMSAR sites, and a unique source of groundwater (Pekárová et al., 1995; Kroiss et al., 2006; Bači- ková, 2006; Valúchová and Kučárová, 2006; Dulovičová and Velisková 2007).

In recent years, physically based models describing water quality in rivers have become popular, probably because of the recent development in GIS technologies, increase in computer processing power and extensive implementation of monitoring programs. It is also believed that more complex methods would better describe the real-world processes and enable us to use the so called "what-if" scenarios (Garnier et al., 2002). On the other hand, such complex methods require more reliable and robust data sets with respect to temporal and spatial coverage. Successful application of mechanistic models is therefore limited (Romanowicz and $\mathrm{Pe}$ tersen, 2003). Complex models such as the QUAL2E and QSIM models (see e.g. Brown and Barnwell, 1987, Kirchesch and Schoel, 1999) are limited in their application especially in large watersheds. In water resources planning and mediumterm prediction projects, these shortcomings favor the applications of data-driven empirical approaches, since these require fewer inputs and are less computationally demanding. Their weaknesses (data dependence, limits in versatility and extrapolating capabilities outside the range of the data set for which they are calibrated) can be often disregarded when solving water quality management problems for shorter time horizons (several months).

Water quality component time series have generally been explored by examining long-term trends and the nature of annual and intra-annual cycles of the data (Shamshad, 2001; Burt and Worral, 2007; Worral and Burt, 2007). Both of these techniques were used in this paper. Seasonal Auto-Regressive Integrated Moving Average (SARIMA) models were applied to examine the nature of the water quality time series. The primary purpose of this paper is to explore the structure of these data sets, rather than to shed light on the internal processes within the watershed. The partial tasks of this paper are therefore as follows:

1. to examine the long-term trends and seasonality in time series of water quality variables sampled in bi-weekly and monthly intervals on the Danube River at the Bratislava gauging station, 
2. to chose an appropriate SARIMA model and to simulate monthly water quality variables in the Danube River at Bratislava under average and extreme water temperature and flow conditions derived from the past measurements:.

i) average conditions - taken as median flows and water temperature;

ii) low flows and high water temperature; and

iii) high flows and low water temperature.

\section{Long-term and seasonal changes of water quality}

\subsection{Study area and sampling sites}

The Danube River basin is situated in Central and Eastern Europe. The river itself runs over 2,857 $\mathrm{km}$ from the spring at an elevation of 1,078 $\mathrm{m}$ a.s.1. in the Black Forest, Germany, to its delta in the Black Sea, Romania. The catchment area upstream the Bratislava station (1868.75 river $\mathrm{km}$ ) is 131,338 $\mathrm{km}^{2}$. The length of the Danube River in Slovakia is $172 \mathrm{~km}$ (from the confluence of the Morava River to the Ipel' River) (Fig. 1). The long-term mean annual runoff (1901-2000) of the Danube at Bratislava is 63854 mil. $\mathrm{m}^{3}$, with a mean annual discharge of $2025 \mathrm{~m}^{3} \mathrm{~s}^{-1}$ and mean annual specific yield $15.42 \mathrm{1} \mathrm{s}^{-1} \mathrm{~km}^{-2}$. In Slovakia, monitoring of surface water quality is conducted by the Slovak Hydrometeorological Institute, with first measure- ments taken in 1965 (Valúchová and Kučárová, 2006). The monitoring campaigns of the agency continue up to the present time.

Several water quality variables indicating secondary anthropogenic pollution $\left(\mathrm{Cl}^{-}, \mathrm{SO}_{4}{ }^{2-}, \mathrm{NO}_{3}-\mathrm{N}\right)$ have increased manifold since the 1950s (Weilguni and Humpesch, 1999). Because of their direct impact on the groundwater quality in the vicinity of the river, impairment of water quality in the Danube has become more apparent.

After 1990 nutrients loads from the Danube basins to the Western Black Sea coastal area have decreased by $\sim 30 \%$ as compared to 1990 , apparently due to the dramatic reduction in use of fertilizers in eastern European countries (see Fig. 2) as well as phosphorus and nitrogen removal by water treatment plants, and improved agricultural practice in Austria and Germany (Blaschke et al. 2005; Pekárová and Miklánek, 1996).

\subsection{Long-term changes}

The quality of water in the Danube at Bratislava is affected by pollution sources in Germany, Austria, and the Czech Republic, affecting the quality of water through the terminating Morava River and other smaller tributaries (Al-Rekabil et al., 1995). Due to the geographical location of the Bratislava sampling site, detection of any pollution coming from the upper Danube region is possible.



Fig. 1. Danube River basin, water quality sampling sites Bratislava (Slovakia).

Obr. 1. Schéma povodia rieky Dunaj, stanica Bratislava. 

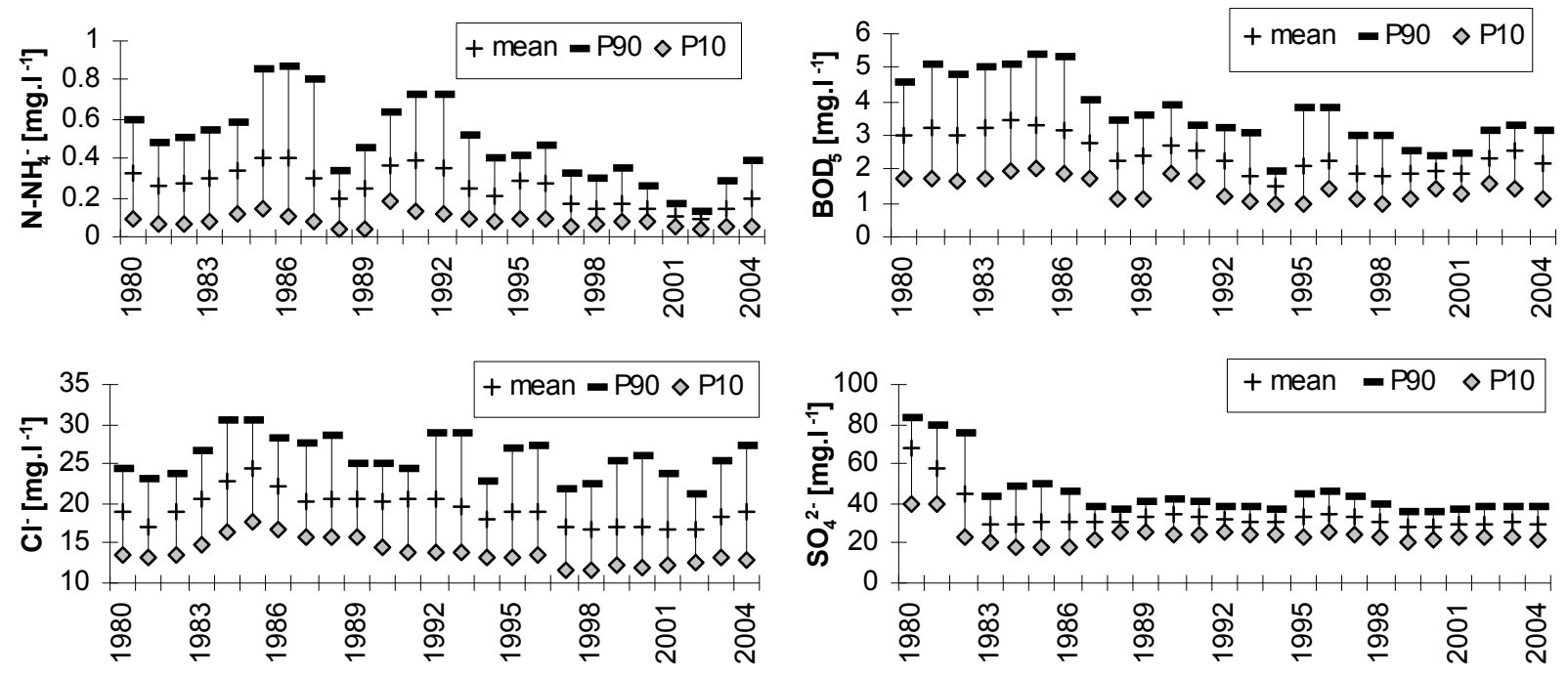

Fig. 2. Selected water quality characteristics (mean, upper-P90 and lover-P10 decile calculated) in Danube River at Bratislava, (1980-2004).

Obr. 2. Priebeh priemerných ročných koncentrácií vybraných ukazovatel’ov kvality vody Dunaja v stanici Bratislava, horný a dolný decil, (1980-2004).

Monthly data measured at the Danube-Bratislava sampling site during the period 1991-2005 were subject to a trend analysis. Over the years 19801989, water quality sampling was carried out once a month, whereas between the years 1990-2003, water samples were taken bi-weekly. All observations made during 1991-2005 were involved in the long-term trend analyses. A selection of water quality variables measured in the Danube River at Bratislava is plotted in Fig. 3. Tab. 1 lists the average values of the chosen water quality variables of the Danube River at Bratislava - taken from the middle of the channel transect, for three five-year periods. The trend analysis reveals that the given time series exhibited significant changes during the last fifteen years - water quality in the upper Danube Basin is improving. For example, a decline in pollutant concentrations can be readily seen in Fig. 2, which is as a result of the introduction of wastewater treatment plants constructed upstream this sampling site (mainly in the Morava basin).

\subsection{Seasonality}

Both the discharge and water quality undergo significant changes over the year (Parajka et al., 2008; Pekárová et al., 1999). In general, if pollution comes from point sources, the water quality deteriorates with decreasing river discharge and increasing water temperature. Each of the studied water quality parameter exhibits intra-annual sea- sonal patterns, as can be seen in Fig. 4. Due to the long-term trend only the period 1996-2005 was used for identification of seasonality. Fig. 4 shows also the long-term monthly river discharge $Q$, and monthly water temperature $T$ at Bratislava. In the case of $Q$ and $T$, average values were calculated from daily observations.

\section{Simulation of water quality}

In this part of the study, linear autoregressive Box-Jenkins models, commonly used to predict water quality parameters, were employed (Box et al., 1994).

\subsection{SARIMA modeling approach}

The Box-Jenkins models represent a reasonable method to describe the periodical time series with essential stochastic behavior (Shamshad, 2001; Komorníková et al., 2008a, b). These models are highly flexible and capable of modeling (stochastically) the seasonality and the trends in a more precise way than conventional analysis techniques. The basic component of these models is an independent and normally distributed random variable $\mathrm{E}_{\mathrm{t}}$ (Pekárová and Pekár, 2006).

The ARMA(p, q) model of order $p$ and $q$ can be defined as a combination of the AR (autoregressive) and MA (moving average) processes and can be described in the following form 



Fig. 3. Average daily discharge $Q d$, daily water temperature $T d$, and (bi)-monthly measured water quality variables, Danube Bratislava, 1990-2006.

Obr. 3. Priebeh priemerných denných prietokov $Q d$ a teploty vody $T d$ a dvojtýždňové alebo mesačné hodnoty koncentrácií vybraných ukazovatel'ov v toku Dunaja v stanici Bratislava, 1990-2006. 
$\mathrm{T} \mathrm{a} \mathrm{b} 1 \mathrm{e}$ 1. Average values of selected pollutant concentrations in the Danube at Bratislava - middle for five-years periods, annual long-term linear trend in period 1991-2005.

T a b u l' k a 1. Priemerné hodnoty vybraných ukazovatel'ov kvality vody Ddunaja v Bratislave-stred za 5-ročné obdobia; dlhoročný lineárny trend za obdobie 1991-2005.

\begin{tabular}{|c|c|c|c|c|c|c|c|c|c|c|}
\hline & $\begin{array}{c}\mathrm{O}_{2} \\
{\left[\mathrm{mg} \mathrm{l}^{-1}\right]}\end{array}$ & $\begin{array}{c}\% \mathrm{O}_{2} \\
\%\end{array}$ & $\begin{array}{l}\mathrm{BOD}_{5} \\
{\left[\mathrm{mg} \mathrm{l}^{-1}\right]}\end{array}$ & $\begin{array}{l}\mathrm{COD}_{\mathrm{Cr}} \mathrm{r} \\
{\left[\mathrm{mg} \mathrm{l}^{-1}\right]}\end{array}$ & $\begin{array}{l}\mathrm{COD}_{\mathrm{Mn}} \\
{\left[\mathrm{mg} \mathrm{l}^{-1}\right]}\end{array}$ & $\begin{array}{c}\text { TOC } \\
{\left[\mathrm{mg} \mathrm{l}^{-1}\right]}\end{array}$ & $\mathrm{pH}$ & $\begin{array}{c}\mathrm{EC} \\
{\left[\mathrm{mS} \mathrm{m}^{-1}\right]}\end{array}$ & $\begin{array}{l}\mathrm{N}-\mathrm{NH}_{4} \\
{\left[\mathrm{mg} \mathrm{l}^{-1}\right]}\end{array}$ & $\begin{array}{l}\mathrm{NO}_{2}-\mathrm{N} \\
{\left[\mathrm{mg} \mathrm{l}^{-1}\right]}\end{array}$ \\
\hline 1991-1995 & 10.2 & 92.4 & 2.05 & 11.58 & 4.09 & 2.77 & 8.08 & 37.8 & 0.298 & 0.026 \\
\hline 1996-2000 & 10.5 & 93.1 & 1.97 & 11.40 & 3.92 & 3.33 & 8.15 & 37.6 & 0.199 & 0.022 \\
\hline 2001-2005 & 10.6 & 94.6 & 2.07 & 11.45 & 3.73 & 2.68 & 8.17 & 39.3 & 0.147 & 0.017 \\
\hline \multirow[t]{2}{*}{ Annual trend } & 0.022 & 0.229 & -0.018 & -0.081 & -0.051 & -0.026 & 0.011 & 0.128 & -0.016 & -0.001 \\
\hline & $\begin{array}{l}\mathrm{NO}_{3}-\mathrm{N} \\
{\left[\mathrm{mg} \mathrm{l}^{-1}\right]}\end{array}$ & $\begin{array}{c}\mathrm{N}_{\text {tot }} \\
{\left[\mathrm{mg} \mathrm{l}^{-1}\right]}\end{array}$ & $\begin{array}{c}\mathrm{PO}_{4}-\mathrm{P} \\
{\left[\mathrm{mg} \mathrm{l}^{-1}\right]}\end{array}$ & $\begin{array}{c}\mathrm{P}_{\text {tot }} \\
{\left[\mathrm{mg} \mathrm{l}^{-1}\right]}\end{array}$ & $\begin{array}{c}\mathrm{Cl}^{-} \\
{\left[\mathrm{mg} \mathrm{l}^{-1}\right]}\end{array}$ & $\begin{array}{c}\mathrm{SO}_{4}^{2-} \\
{\left[\mathrm{mg} \mathrm{l}^{-1}\right]}\end{array}$ & $\begin{array}{c}\mathrm{Ca} \\
{\left[\mathrm{mg} \mathrm{l}^{-1}\right]}\end{array}$ & $\begin{array}{c}\mathrm{Mg} \\
{\left[\mathrm{mg} \mathrm{l}^{-1}\right]}\end{array}$ & $\begin{array}{c}\mathrm{KNK} \\
{\left[\mathrm{mmol} \mathrm{l}^{-1}\right]}\end{array}$ & $\begin{array}{c}\text { Clf-a } \\
{\left[\mu \mathrm{g} \mathrm{l}^{-1}\right]}\end{array}$ \\
\hline 1991-1995 & 2.374 & 3.074 & 0.064 & 0.127 & 19.4 & 32.7 & 57.1 & 12.1 & 3.04 & 14.12 \\
\hline 1996-2000 & 2.352 & 3.054 & 0.052 & 0.090 & 17.4 & 31.3 & 56.4 & 13.5 & 3.02 & 14.47 \\
\hline $2001-2005$ & 2.113 & 2.628 & 0.044 & 0.091 & 17.6 & 28.9 & 54.6 & 12.8 & 3.07 & 14.31 \\
\hline Annual trend & -0.031 & -0.048 & -0.002 & -0.004 & -0.219 & -0.496 & -0.367 & 0.011 & 0 & -0.007 \\
\hline
\end{tabular}
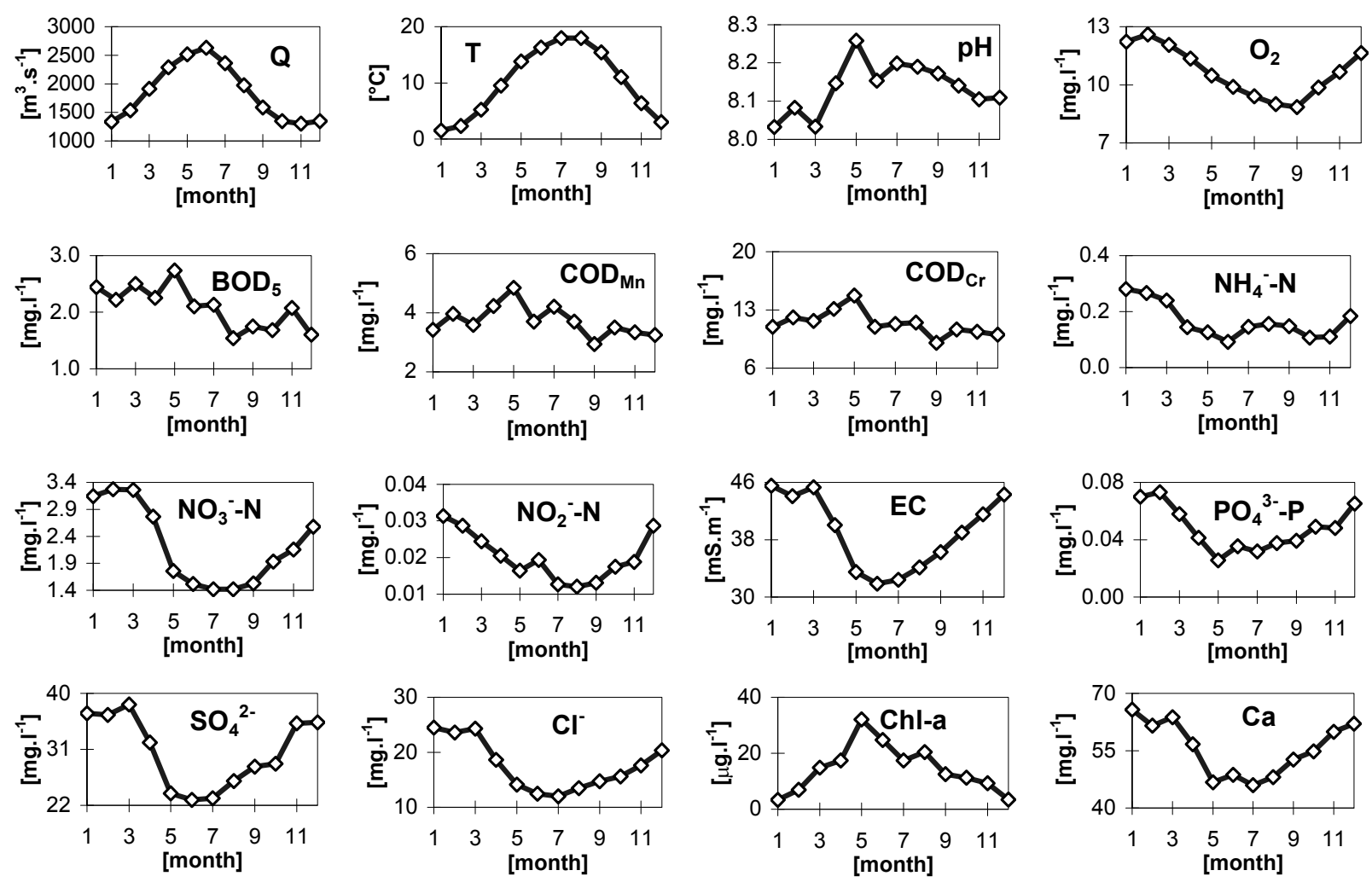

Fig. 4. Monthly regime of discharge, water temperature and concentrations of selected water quality variables (averages for 1996-2005) in the Danube River at Bratislava.

Obr. 4. Ročný chod prietokov, teploty vody a koncentrácií vybraných prvkov, (priemery za obdobie 1996-2005), Dunaj, Bratislava.

$\mathrm{Y}_{\mathrm{t}}=\varphi_{1} \mathrm{Y}_{\mathrm{t}-1}+\ldots+\varphi_{\mathrm{p}} \mathrm{Y}_{\mathrm{t}-\mathrm{p}}+\mathrm{E}_{\mathrm{t}}+$

$+\Theta_{1} \mathrm{E}_{\mathrm{t}-1}+\ldots+\Theta_{\mathrm{q}} \mathrm{E}_{\mathrm{t}-\mathrm{q}}$,

where $E_{t}$ - independent and normally distributed random variable with zero mean value $\mu=$ $=0$ and variance $\sigma_{\mathrm{E}}^{2}$,

$\Theta_{i}$ - parameters of MA polynomial of order $q$,

$\varphi_{i}$ - parameters of AR polynomial of order $p$.
In an operator-based form, the model can be written as:

$\varphi(B) Y_{t}=\Theta(B) E_{t}$,

where $\mathrm{B}-$ reversion shift operator defined as $B Y_{t}=$ $=\mathrm{Y}_{\mathrm{t}-1}$,

$\Theta$-regular MA operator of order $q$,

$\varphi$-regular AR operator of order $p$. 
In designing the ARIMA(p, d, q) model, stationarity of the analyzed series (Y) is not required. Instead of the original series, this model operates with series $(Z)$ of differences of the first order or any higher order. For the differences of the first order, the following applies:

$Z_{\mathrm{t}}=\mathrm{Y}_{\mathrm{t}}-\mathrm{Y}_{\mathrm{t}-1}, \mathrm{Z}_{\mathrm{t}-1}=\mathrm{Y}_{\mathrm{t}-1}-\mathrm{Y}_{\mathrm{t}-2}, \ldots$, .

The generalized operator form is:

$\mathrm{Z}_{\mathrm{t}}=\nabla^{1} \mathrm{Y}_{\mathrm{t}}=(1-\mathrm{B}) \mathrm{Y}_{\mathrm{t}}$

where: $\nabla^{1}-$ the backwards difference operator.

The final form of the ARIMA model can be written as:

$\varphi(\mathrm{B}) \nabla^{\mathrm{d}} \mathrm{Y}_{\mathrm{t}}=\Theta(\mathrm{B}) \mathrm{E}_{\mathrm{t}}$

In the B-J methodology, the seasonality as well as the trend are modeled stochastically. The general form of the SARIMA(p,d,q)x(P,D,Q) $)_{12}$ model takes the following form:

$\varphi(\mathrm{B}) \varphi\left(\mathrm{B}^{12}\right) \nabla^{\mathrm{d}} \nabla_{12} \mathrm{Y}_{\mathrm{t}}=\Theta(\mathrm{B}) \Theta\left(\mathrm{B}^{12}\right) \mathrm{E}_{\mathrm{t}}$,

where $\nabla_{12}^{P}$-the seasonal backwards difference operator,

$\varphi$ - the regular SAR (seasonal autoregressive) operator of the order $\mathrm{p}$,

$\Theta-\quad$ the regular SMA (seasonal moving average) operator of the order $\mathrm{q}$.

\subsection{Model selection}

Now, having analyzed the past 25 years, we found that in order to predict water quality in the Danube, only the last 10-15 years with water quality data are needed. Therefore the monthly values (in the case of bi-weekly observations taken as the first value) of water quality for the period 1993-2005 were treated as a time series that was used for the simulation. Eleven years of record (1993-2003) were used for calibration of the model. Validation of the models was performed on the 2004-2005 data.

Time series of actual water quality data as well as the estimated autocorrelation and partial autocorrelation functions of the observed series were used in constructing the models. When necessary, the trend (non-stationarity) in the series was removed by applying differentiation of the first order $(\mathrm{D}=$ $=1$ ). The distribution of observed concentrations is not Gauss-normal, therefore a logarithmic transformation was applied to the input time series before the actual simulation.

On the basis of the model efficiency, following five types of autoregressive models SARIMA $(\mathrm{p}, \mathrm{d}, \mathrm{q}) \mathrm{x}(\mathrm{P}, \mathrm{D}, \mathrm{Q})_{12}$ models with two regressors water temperature $T$ and discharge $Q$ (measured coincidently with quality sampling) were chosen:

(A) SARIMA $(0,0,0) \times(1,1,0)_{12}+2$ regressors, Math adjustment: Log base 10

(B) $\operatorname{SARIMA}(0,0,0) \times(1,0,0)_{12}$ with constant +2 regressors, Math adjustment: Log base 10

(C) $\operatorname{SARIMA}(0,0,0) \times(1,0,0)_{12}+2$ regressors, Math adjustment: Log base 10

(D) $\operatorname{SARIMA}(0,0,1) \times(1,0,0)_{12}$ with constant +2 regressors, Math adjustment: Log base 10

(E) SARIMA $(0,0,1) \times(1,0,0)_{12}+2$ regressors, Math adjustment: Log base 10

In selecting the most appropriate SARIMA model one should follow the following rule of thumb: a better model should yield lower MSE (mean square error) and MAE (mean average error), while ME (mean error) and MPE (mean percentage error) should be close zero. Tab. 2 . lists the results of an error analysis for chlorophyll-a for two time periods: calibration period 1993-2003, and validation period 2004-2005. Having completely adopted this rule and examining the error statistics reveals that models " $\mathrm{A}$ " and " $\mathrm{D}$ " can be seen as the worst and best choices. For illustration, in Fig. 5 are shown the results for chlorophyll-a using the (A) and (D) model, respectively. However, here it should be noted that relying merely on the rule outlined above may result in a wrong choice; in other words, the modeler's subjective intervention in selecting an appropriate model remains crucial, especially if there is not much difference in the error statistics between the proposed models. For example, model "A" seems to better fit the peak values in chlorophyll concentrations than the model "D", and thus it might be regarded as a more appropriate model (Fig. 5). Nonetheless, each of the investigated variables was assigned the model " $\mathrm{D}$ ", as the model with the best performance results based on the error analysis and subjective interpretation. Additionally, several variants of the presented models can be chosen for each variable being studied. 
T a b 1 e 2. Models (A) to (E). A comparison for chlorophyll-a, MSE - mean square error, MAE - mean absolute error, MAPE mean absolute percentage error, ME - mean error, MPE - mean percentage error.

T a b u l' k a 2. Porovnanie modelov (A) až (E) pre chlorofyl-a, MSE - stredná kvadratická chyba, MAE - stredná absolútna chyba, MAPE - stredná absolútna percentuálna chyba, ME - stredná chyba, MPE - stredná percentuálna chyba.

\begin{tabular}{llllll}
\hline \multirow{2}{*}{ Model } & \multicolumn{5}{c}{ Estimation period 1993-2003 } \\
\hline (A) & 234.91 & 8.679 & 81.93 & 2.316 & MPE \\
(B) & 191.19 & 7.773 & 79.15 & 3.434 & -33.57 \\
(C) & 233.62 & 8.620 & 86.89 & 1.928 & -37.29 \\
(D) & 185.58 & 7.695 & 77.46 & 3.295 & -34.83 \\
(E) & 199.11 & 8.208 & 77.25 & 2.943 & -24.47 \\
\hline \multicolumn{7}{r}{ Model } & MSE & MAE & MAPE & ME & MPE \\
\hline (A) & 108.34 & 7.575 & 54.79 & 1.931 & 1.259 \\
(B) & 90.46 & 7.142 & 63.59 & 4.092 & -3.502 \\
(C) & 101.1 & 7.339 & 61.34 & 2.260 & -2.690 \\
(D) & 83.24 & 7.042 & 62.02 & 3.865 & -5.785 \\
(E) & 90.95 & 7.486 & 61.08 & 3.874 & 4.944 \\
\hline
\end{tabular}

\subsection{Simulation of extreme discharge and temperature scenario}

In order to create scenarios of extreme values of the selected water quality variables for each month, three types of possible flow and water temperature conditions were examined:

i) average conditions determined as median temperature (T50) and average flows $(Q 50)$;

ii) highest temperatures (T99) and lowest flows $(Q 01)$, and

iii) lowest temperatures (T01) and highest flows (Q99).

These conditions were derived for each month using daily observations of water temperature and daily discharge readings at Bratislava over the period $1931-2005$ as percentiles $\left(1^{\text {th }}-\right.$ percentile, median, $99^{\text {th }}$-percentile) (Fig. 6). Intra-annual simulation of chlorophyll-a and nitrate nitrogen is shown for illustration below (Fig. 7). The maximum concentrations of chlorophyll can be expected under low flow conditions $(Q 01)$ and high water temperatures (799). In the case of nitrate-nitrogen, the situation is not so obvious. Nitrogen is introduced into the Danube's water mainly through diffusion sources from agriculture. This fact can be explained by the higher simulated concentrations under high flow conditions $(Q 99)$, whereas under low-flow con-

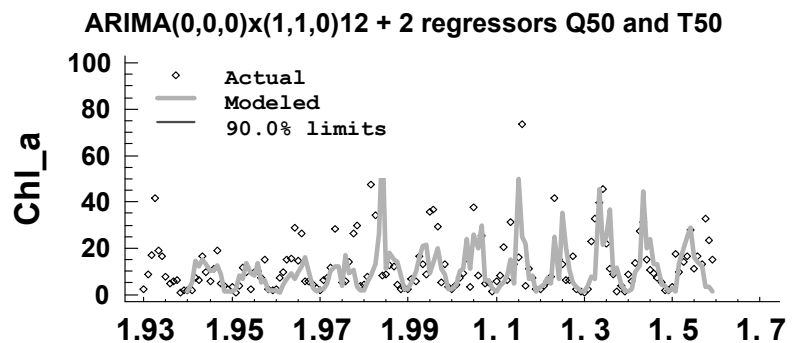

$\operatorname{ARIMA}(0,0,1) \times(1,0,0) 12$ with constant +2 regressors $Q 50$ and $T$ !

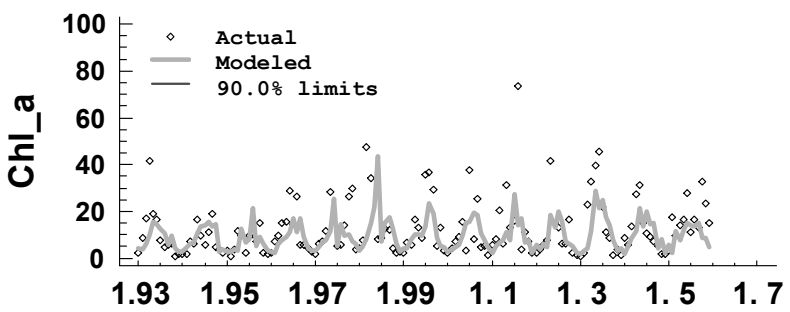

\begin{tabular}{llll|llll}
\hline Model (A) & & & & Model (D) & & & \\
\hline Parameter & Estimate & Stnd. Error & P-value & Parameter & Estimate & Stnd. Error & P-value \\
\hline SAR(1) & -0.4554 & 0.0764 & 0.00000 & MA(1) & -0.2666 & 0.08836 & 0.0029 \\
Q50 & -0.00011 & 0.000025 & 0.00001 & SAR(1) & 0.3658 & 0.08813 & 0.00005 \\
T50 & 0.02052 & 0.00495 & 0.00006 & Q50 & -0.000106 & 0.0000317 & 0.00108 \\
& & & & T50 & 0.02984 & 0.0060746 & 0.00000 \\
& & & Mean & 0.7462 & 0.136415 & 0.00000 \\
\end{tabular}

Fig. 5. Comparison of two models (A and D) for chlorophyll-a, monthly modeled values for measured discharge and water temperature values (1.93 - denotes January 1993).

Obr. 5 Porovnanie dvoch modelov (A a D), modelované mesačné koncentrácie chlorofylu-a pre merané prietoky a teplotu vody (1.93 znamená január 1993). 



Fig. 6. Scenarios of average daily water temperatures $T$ and average daily discharge (1931-2005). P1 denotes first percentile, P99 denotes 99.-percentile.

Obr. 6. Scenárové hodnoty pre prietok a teplotu vody vypočítané z denných meraní za obdobie 1931-2005. P1 je 1. percentil, P99 je 99. percentil.

SARIMA $(0,0,1) \times(1,0,0) 12$ with constant + 2 regressors, Q99, T0 SARIMA $(0,0,1) \times(1,0,0) 12$ with constant + 2 regressors, Q99, T01
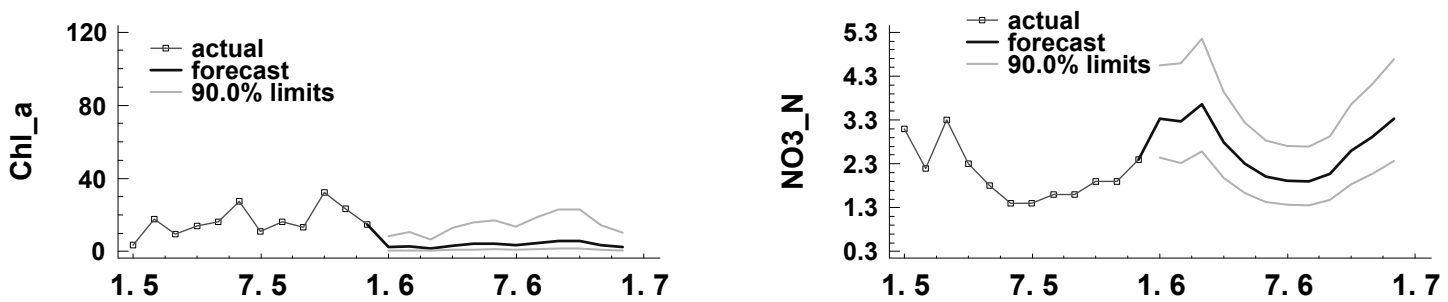

$\operatorname{SARIMA}(0,0,1) \times(1,0,0) 12$ with constant +2 regressors, $Q 50$, T5

SARIMA $(0,0,1) \times(1,0,0) 12$ with constant +2 regressors, $Q 50$, T50
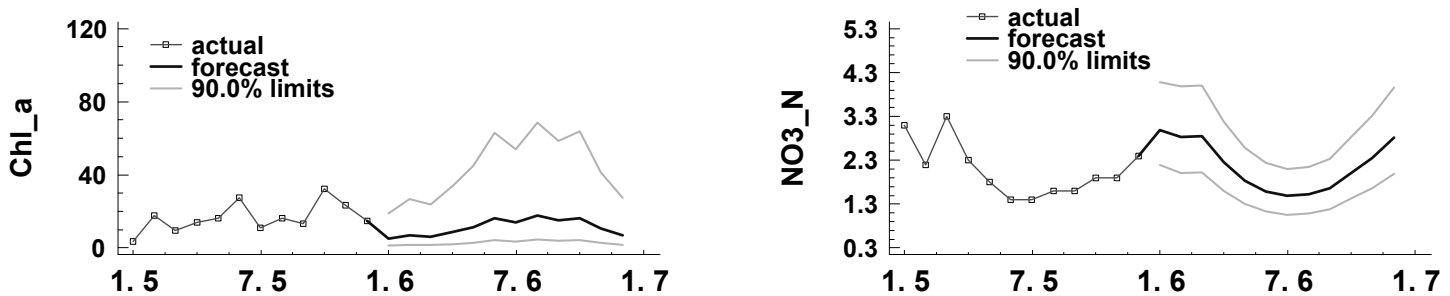

$\operatorname{SARIMA}(0,0,1) \times(1,0,0) 12$ with constant +2 regressors, $Q 01, T 9$

SARIMA $(0,0,1) \times(1,0,0) 12$ with constant +2 regressors, Q01, T99
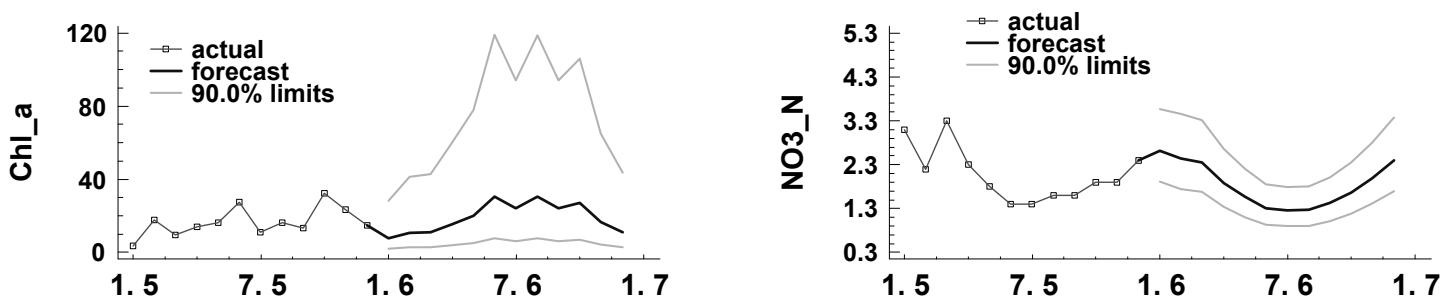

Fig. 7. Simulation of: chlorophyll-a and nitrate-nitrogen concentrations by SARIMA models, (dark line), Danube Bratislava, $90 \%$ upper and 10\% lover confidential limits (light lines); measured values in the year 2005 (dots).

Obr. 7. Simulácia chlorofylu-a (vl’avo) a dusičnanového dusíka (vpravo) modelom SARIMA s dvoma regresormi, 90\% horný a 10\% dolný limit (svetlé čiary); merané hodnoty 2005 (body) a simulácia na rok 2006, (1.5 znamená január 2005). 
ditions, nitrogen-nitrate exhibits lower concentrations. Discharge acts as a dilution factor in variables such as phosphorus and chlorophyll, while dissolved oxygen appears to be less dischargerelated.

\subsection{Long-term prediction}

The calibrated models can be used for long-term prediction of monthly values of the water quality variables, and linked to future scenarios of water temperature and discharge. Prediction was made for seven years ahead (period 2006-2012). For prediction, monthly medians of discharge and monthly medians of temperature were used as inputs into the models. The modeling results are shown in Fig. 8. The predicted values of the upper $90 \%$ limit are rather high (in the case of oxygen, the low values are extreme), hence these values represent the $c_{90}$ percentile required for classification of the Danube according to the Water Framework Directive WFD, 2000/60/EC. Moreover, values of $c_{90}$ have been determined for each month separately.


SARIMA $(0,0,1) \times(1,0,0) 12$ with constant +2 regressors $Q 50$ and
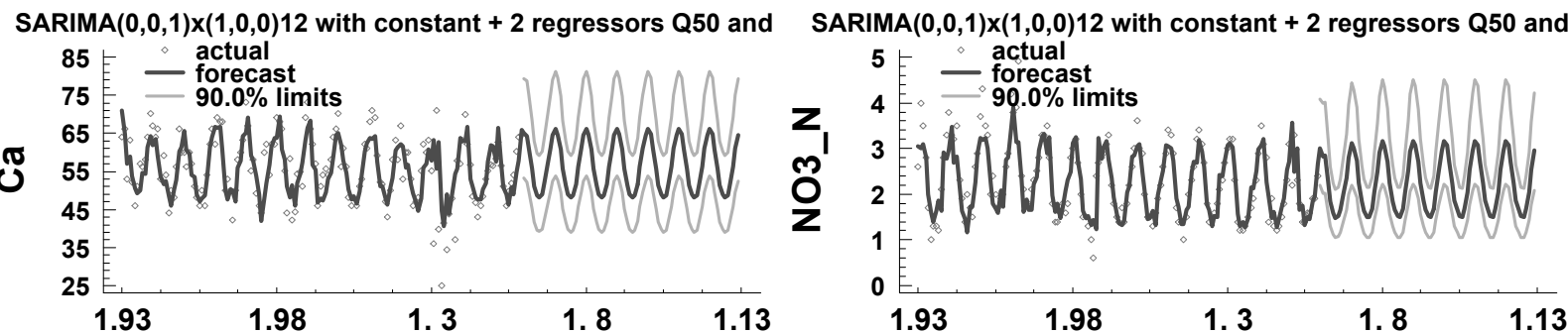

SARIMA $(0,0,1) \times(1,0,0) 12$ with constant +2 regressors $Q 50$ and $T$


Fig. 8. Long-term monthly prediction for median monthly discharge and water temperature, period 2006-2012, Danube at the Bratislava gauge.

Obr. 8. Dlhodobá predpoved' vybraných ukazovatel'ov kvality vody pre mediánové mesačné prietoky a teploty vody. Obdobie 2006-2012, Dunaj: Bratislava. 


\section{Conclusions}

Our ability to predict water quality and the ecological state of streams is essential in terms of proposing effective measure for maintaining ecological sustainability of water resources. Another important aspect of water quality modeling is to adequately respond to changes in the use of water resources, e.g. construction of water reservoirs and water withdrawal for irrigation and industrial purposes. It is widely recognized that maintaining ecologically acceptable low flows below reservoirs and withdrawal sites should be of concern to water managers before issuing water right permits. Thus, every attempt to change the natural flow conditions of a stream should be accompanied with reliable simulations of possible impacts of a proposed modification on the stream's ecology and water quality. In this study we used one of possible techniques for simulations of how the Danube River may respond to different flow conditions, i.e. extremely low flows and high flows. This study can serve as an example of how seasonal autoregressive movingaverage models (SARIMA) might be used for such purposes. The trend analysis of time series in which monthly concentrations of the selected variables were used indicates that the quality of water in the Danube at Bratislava has improved over the past fifteen years. As for chlorophyll-a, it is also widely accepted that concentration of chlorophyll-a depends on light conditions primarily determined by the light attenuation by suspended matter and dissolved substances (yellow substances, or "Gelbstoffe"), and water temperature. Since suspended load is controlled by discharge, the range of chlorophyll-a concentrations is predictable by means of SARIMA models provided that river discharge and water temperature are used as input variables, and nutrients are available in sufficient amounts. In the case of dissolved oxygen and electrical conductivity, the range of simulated values is not so broad as in the case of chlorophyll-a. Therefore, these variables are predictable with a narrower confidential limit. The forecasting performance of the SARIMA models is good. We consider the obtained results satisfactory and, as such, the results might provide us with a "big" picture of what can be expected in the Danube River in terms of water quality under extreme flow and water temperature conditions. This study reveals that it is feasible to simulate water quality in the Danube River by means of autoregressive models, but future investi- gations should be conducted on other and smaller rivers to confirm these results in order to generalize these conclusions.

Acknowledgement. This study was supported by Science and Technology Agency (Slovakia) under contract No. APVV 0443/07 and by the Science Granting Agency under the contract No. VEGA $1 / 3767 / 06$.

\section{REFERENCES}

AL-REKABI1 H., SOJÁK L., KMINIAK M., 1995: Volatile organic compounds in water and sediment from the Morava and the Danube Rivers (Slovakia) using purge and trap injection and gas chromatography. Water, Air, \& Soil Pollution, 81, 1-2, 193-200.

ANTONOPOULOS V.Z., PAPAMICHAIL D.M., MITSIOU K.A., 2001: Statistical and trend analysis of water quality and quantity data for the Strymon River in Greece. Hydrology and Earth System Sciences, 5, 4, 679-691.

BAČÍKOVÁ S., 2006: Impact of the Gabčíkovo hydraulic structures on the Danube water quality, chapter V.1.11. In: Danube Monitoring Scientific Mosonmagyaróvár Conference Publication, Bratislava, 103.

BLASCHKE A.A.P., SCHILLING B.C., ZESSNER C.M., 2005: Danubs - nutrient management in the Danube basin and its impact on the Black Sea - The role of the water balance calculations. Geophysical Research Abstracts, Vol. 7, 08255 , pp. 3.

BLOESCH J., 2006: The ultimate need for the implementation of sturgeon protection in the Danube River Basin - a view of 2006 and call for actions with the Sturgeon Action Plan under the Bern Convention. Proceedings 36th International Conference of IAD, 132-136. Austrian Committee Danube Research/IAD, Vienna.

BONDAR C., HARABAGIU E., STATE G., 1990: The evolution in time (1946-1989) of the salt run-off on the Danube from the inlet at the Romanian border to the outlet into the Black sea. Meteorology and Hydrology, 20, 2, 33-38.

BOX G.E.P., JENKINS G.M., REINSEL G.C., 1994: Time Series Analysis, Forecasting and Control, 3rd ed. Prentice Hall, Englewood Clifs, NJ.

BOTTERWEG T., RODDA D.W., 1999: Danube River basin: Progress with the environmental programme. Water Science and Technology. 40, 10, 1-8.

BROWN L., BARNWELL T., 1987: The enhancement stream quality models QUAL2E and QUAL2E-UNCAS: Documentation and User Manual. Environmental Research Laboratory.

BURT T., WORRALL F., 2007: Non-stationarity in long time series: some curious reversals in the 'memory' effect. Hydrological Processes, 21, 3529-3531.

DULOVIČOVÁ R., VELÍSKOVÁ Y., 2007: Change of Zitny Ostrov channel network. J. Hydrol. Hydromech., 55, 3, 185-198.

GARNIER J., BILLEN G., HANNON E., FONBONNE S., VIDENINA Y., SOULIE M., 2002: Modelling the transfer and retention of nutrients in the drainage network of the Danube River estuarine. Coastal and Shelf Science, 54, 3, 285-308. 
CHALUPOVA D., JANSKY B., 2007: Anthropogenic impact on selected oxbow lakes in the Elbe River floodplain. J. Hydrol. Hydromech., 55, 2, 86-97.

KIRCHESCH V., SCHOEL A., 1999: Das Gewaesserguetemodell QSIM - Ein Instrument zur Simulation des Stoffhaushalts und der Phytoplnaktondynamic von Fliessgewaessern. Hydrologie und Wasserbewirtschaftung, 43, 302-309.

KOMORNÍK J., KOMORNÍKOVÁ M., MESIAR R., SZÖKEOVÁ D., SZOLGAY J., 2006: Comparison of forecasting performance of nonlinear models of hydrological time series. Physics and Chemistry of the Earth, 31, 18, $1127-1145$.

KOMORNÍKOVÁ M., SZOLGAY J., SVETLÍKOVÁ D., SZÖKEOVÁ D., 2008a: Combined deterministic-stochastic forecasting of monthly river flows. Geophysical Research Abstracts, EGU General Assembly, Vol. 10, EGU2008-A05501, SRef-ID: 1607-7962/gra/EGU2008-A-05501.

KOMORNÍKOVÁ M., SZOLGAY J., SVETLÍKOVÁ D., SZÖKEOVÁ D., JURČ́AK S., 2008b: A hybrid modeling framework for forecasting monthly reservoir inflows. J. Hydrol. Hydromech., 56, 3, 145-162.

KRIZAN J., MILORADOV M., 1997: Water quality of Yugoslav rivers (1991-1995). Water Research., 31, 11, 2914 $-2917$.

KROISS H., ZESSNER M., LAMPERT C., 2006: DaNUbs: Lessons learned for nutrient management in the Danube Basin and its relation to Black Sea euthrophication. Chemistry and Ecology, 22, 5, 347-357.

LANGHAMMER J., 2005: Classification of the dynamics of water quality changes in the Elbe River basin. J. Hydrol. Hydromech., 53, 4, 205-218.

LITERÁTHY P., 1975: Study of river pollution caused by micropollutants. Water Research, 9, 1, 1001-1003.

PARAJKA J., MERZ R., SZOLGAY J., BLÖSCHL G., KOHNOVÁ S., HLAVCOVÁ K., 2008: A comparison of precipitation and runoff seasonality in Slovakia and Austria. Meteorological J., 11, 9-14.

PEKÁROVÁ P., MIKLÁNEK P., 1996: Trend change of nitrate in Slovakia during 1968-1993. Acta Geologica Hispanica, 28, 2-3, 55-63.

PEKÁROVÁ P. MIKLÁNEK P. RONČÁK P., 1995: Stream load and specific yield of nitrogen and phosphates from Slovakia. J. Hydrol. Hydromech., 43, 4-5, 233-248.

PEKÁROVÁ P., PEKÁR J., MIKLÁNEK P., RONČÁK P., 1999: Temporal and spatial changes of water quality in the Slovak part of Danube River. In Environmental Protection of Soil and Water Resources (Ed. G.J. Halasi-Kun). Columbia University Seminar Proceedings, Vol. XXX, p. 7-31.

RAGAVAN A.J., FERNANDEZ J.C., 2006: Modeling Water Quality Trend in Long Term Time Series. Paper 205-31, SUGI 31 Proceedings.

REICHEL G., NACHTNEBEL H.P., 1994: Suspended sediment monitoring in a fluvial environment: Advantages and limitations applying an Acoustic Doppler Current Profiler. Water Research., 28, 4, 751-761.

ROMANOWICZ R.J., PETERSEN W., 2003: Modelling algae concentrations in Elbe in the years 1985-2001 using observations of daily oxygen concentrations, temperature and $\mathrm{pH}$. Acta Hydrochimica et Hydrobiologica, 31, 319-333.

SHAMSHAD AHMAD, IQBAL H. KHAN, PARIDA B.P., 2001: Performance of stochastic approaches for forecasting river water quality. Water Research, 35, 18 4261-4266.
SEBÍŇ M., PEKÁROVÁ P., MIKLÁNEK P., 2007: Nitrate wash off from the Bratislava Forest Park basin Vydrica in years 1986-2005. J. Hydrol. Hydromech., 55, 3, 145-155.

SOMLYÓDY L., BRUNNERAND P.H., KROIB H., 1999: Nutrient balances for Danube countries: A strategic analysis. Water Science and Technology, 40, 10, 9-16.

SVETLÍKOVÁ D., KOMORNÍKOVÁ M., KOHNOVÁ S., SZOLGAY J., HLAVČOVÁ K., 2008: Analysis of discharge and rainfall time series in the region of the Káštorské lúky wetland in Slovakia. XXIVth conference of the Danubian countries on the hydrological forecasting. Conference E-papers. Bled, 12 pp.

VALÚCHOVÁ M., KUČÁROVÁ K., 2006: Monitoring of surface waters and sediment quality in the area influenced by the Gabčíkovo hydraulic structures, chapter V.1.10. In: Danube Monitoring Scientific Mosonmagyaróvár Conference Publication, Slovak Section, Bratislava, 91-102.

VELIKOV B., MACHKOVA M, DIMITROV D., MILUSHEV I., 1996: Tendencies in the dynamics of the hydrochemical parameters in the Danube waters, its tributaries and groundwater in Bulgarian part of the river basin. In Proceedings of XVIIIth Conference of the Danube Countries on hydrological forecasting and hydrological bases and water management data. TU Graz, Austria, Vol. 2, E9-16.

WEILGUNI H., HUMPESCH U. H., 1999: Long-term trends of physical, chemical and biological variables in the River Danube 1957-1995: A statistical approach. Aquat. Sci., 61, 234-259.

WFD 2000/60/EC of the European Parlament and of the Council of the 23 October 2000 , establishing a framework for Community action in the field of water policy.

WOLF B., 1996: Water quality of the River Danube in Bavaria. In Proceedings of XVIIIth Conference of the Danube Countries on hydrological forecasting and hydrological bases and water management data. TU Graz, Austria, Vol. 2, E25-30.

WORRALL F., BURT T.P., 2007: Trends in DOC concentration in Great Britain. ScienceDirect, 346, 81-92.

Received 13. June 2008 Scientific paper accepted 16. October 2008

\section{PREDPOVEĎ VYBRANÝCH UKAZOVATELOV KVALITY VODY V DUNAJI ZA EXTRÉMNYCH HYDROLOGICKÝCH A TEPLOTNÝCH PODMIENOK}

Pavla Pekárová, Milan Onderka, Ján Pekár, Peter Rončák, Pavol Miklánek

Jedným z negatívnych dôsledkov očakávaného otepl'ovania sa prostredia má byt' aj zvyšovanie teploty vody v tokoch, znižovanie prietokov počas letných sezón a tým aj následné zhoršovanie kvality vody $\mathrm{v}$ tokoch. Ciel'om tejto štúdie je návrh modelu, ktorým by sme mohli simulovat' extrémne prietokové a teplotné situácie a odhadovat' ním extrémne koncentrácie vybraných polutantov v povrchovom toku.

V prvej časti príspevku sa analyzuje vývoj mesačných koncentrácií vybraných ukazovatel'ov kvality vody v toku Dunaja v stanici Bratislava (napr. Chl-a, Ca, EC, 
$\mathrm{SO}_{4}{ }^{2-}, \mathrm{Cl}^{-}, \mathrm{O}_{2}, \mathrm{BSK}_{5}, \mathrm{~N}$-celk, $\mathrm{PO}_{4}-\mathrm{P}, \mathrm{NO}_{3}-\mathrm{N}, \mathrm{NO}_{2}-\mathrm{N}$ a pod.) za obdobie 1991-2005.

Druhá čast' je venovaná výberu vhodného typu sezónneho autoregresného Box-Jenkinsonovho modelu s dvoma regresormi (prietokmi a teplotami vody) pre každý ukazovatel' kvality vody. V prvom kroku boli odvodenými modelmi predpovedané koncentrácie jednotlivých ukazovatel'ov na 7 rokov dopredu (2006-2012) za priemerných hydrologických podmienok - mediánové mesačné prietoky a teploty vody.

$\mathrm{Na}$ vytvorenie scenárov vývoja mesačných koncentrácií vybraných ukazovatel'ov kvality vody v toku Dunaja pre budúce obdobie boli zostavené viaceré autoregresné modely s dvoma regresormi: 1. prietokmi; a 2 . teplotami vody. Scenáre pre mesačné prietoky a mesačné teploty vody boli vytvorené pre tri stavy: i) priemerné podmienky - medián prietokov a teploty vody; ii) nízke prietoky a vysoké teploty vody; a iii) vysoké prietoky a nízke teploty vody. Tieto scenárové podmienky boli vypočítané $\mathrm{z}$ denných údajov $\mathrm{z}$ obdobia 1931-2005 ako percentily (1. percentil, medián, 99. percentil). Použijúc tieto scenáre sme Box-Jenkinsovými modelmi s dvoma regresormi simulovali extrémne mesačné hodnoty vybraných ukazovatel'om kvality vody v Dunaji (paragraf 3.3). V poslednom paragrafe 3.4 sme vybrané modely použili na dlhodobú predpoved' mesačných hodnôt vybraných ukazovatel'ov kvality vody. Hodnotu 90\% horného limitu možno porovnat' s hodnotou $\mathrm{C}_{90}$ a zistit' tak očakávané zatriedenie vody Dunaja v Bratislave do jednotlivých tried kvality v zmysle WFD, 2000/60/EC. 